\title{
Briefly
}

Published at www.cmaj.ca between

Aug. 31 and Sept. 10

Palliative options: Over the objections of its medical society, New York State will require all physicians to inform patients with terminal illnesses about their options for palliative and end-oflife care. The physician "shall offer to provide the patient with information and counselling regarding palliative care and end-of-life options appropriate to the patient, including but not limited to: the range of options appropriate to the patient, the prognosis, risks and benefits of the various options; and the patient's legal rights to comprehensive pain and symptom management at the end of life," states the legislation, The New York Palliative Care Information Act (http://assembly.state.ny.us/leg/?default _fld=\&bn=+A07617\%09\%09\&Summ $\operatorname{ary}=\mathrm{Y} \&$ Actions $=\mathrm{Y} \& \mathrm{Text}=\mathrm{Y})$. The Medical Society of New York objected to the legislation on the grounds that it would introduce a "legislatively designed standard of care."

Tracking drugs: Ontario Health Minister Deb Matthews has announced that the province will expand its drug tracking system this fall in a bid to curb abuse of painkillers such as oxycodone, morphine and codeine, as well as stimulants and sedatives. The expanded database will "collect, monitor and analyze information related to prescription narcotics and other controlled substances; identify patterns of inappropriate or excessive prescribing or dispensing; implement a province-wide system of alerts when attempts to visit multiple prescribers, or visit multiple pharmacies, are detected; (and) in instances of inappropriate activity, responses could include educational support and resources, reporting to the appropriate regulatory college and, in extreme circumstances, law enforcement," the government said in a release (www.health .gov.on.ca/en/public/programs/drugs/on s/docs/op_reduce_misuse_abuse.pdf).
The expansion is being undertaken as part of the province's response to rampant misuse of prescription painkillers within its borders, which has led rising numbers of residents to seek treatment for opioid addiction (CMAJ 2009; DOI:10.1503/cmaj.109-3032).

\section{Embryonic stem cell research} threatened: United States President Barack Obama's efforts to kickstart embryonic stem cell research were dealt a severe blow when a US District Court judge issued a preliminary injunction against financial support for embryonic stem cell research. The injunction had been sought by researchers Drs. James L. Sherley and Theresa Deisher, along with several groups such as the Christian Medical Association, who claimed that supporting embryonic stem cell research violated a 1996 Congressional law which prohibits federal money being used for scientific research that destroys human embryos. The researchers also argued that their ability to conduct adult stem cell research was compromised because they were being placed in competition for National Institutes of Health funding with researchers using embryonic stem cells. Chief Judge Royce C. Lamberth accepted the latter argument, saying "this increased competition for limited funds is an actual, imminent injury" and among grounds for an injunction (https://ecf.dcd.us courts.gov/cgi-bin/show_public_doc ?2009cv1575-44). The Obama administration is appealing the decision.

\section{Mental health system overhaul} urged: The provision of "core institutional, residential and community" mental health and addiction services in every region of the province, system "navigators" to help patients negotiate appropriate services (such as "housing, income support, employment, peer support and recreational opportunities"), and an overhaul of government management of mental health and addictions programs are among recommendations emerging from the final report of the Ontario Parliament's Select Committee on Mental Health and Addictions. The final report, Navigating the Journey to Wellness: The Comprehensive Mental Health and Addictions Action Plan for Ontarians, recommends that a government agency be created to design, management and coordination of the system, while "all mental health and addictions programs and services for all regions of the province and for all ages, including children and youth - should be consolidated in the Ministry of Health and Long-Term Care" (www.ontla.on.ca/committee-proceed ings/committee-reports/files_pdf/Selec t\%20Report\%20ENG.pdf). Among other recommendations: "The core basket of mental health and addictions services should be available to the incarcerated population, and discharge plans for individuals with a mental illness or addiction should be expanded to include the services of a system navigator and appropriate community services."

Drugs and inflation: Retail prices for 207 brand name drugs rose $41.5 \%$ between 2005 and 2009 in the United States, as compared with a general inflation rate of $13.3 \%$, according to a new study by AARP, a nonprofit organization formerly known as the American Association of Retired Persons. The study, Rx Price Watch Report August 2010: Trends in Retail Prices of Brand Name Prescription Drugs Widely Used by Medicare Beneficiaries 2005 to 2009, also found that, "in 2009, the average annual increase in retail prices for 217 brand name prescription drugs widely used by Medicare beneficiaries was 8.3 percent, and was notably higher than the rate of increase observed during any of the prior four years (i.e., 2005 to 2008), which ranged from 6.0 percent to 7.9 percent. In contrast, the rate of general inflation was -0.3 percent over the same 
period" (http://assets.aarp.org/rgcenter /ppi/health-care/rxpricewatch.pdf).

JAMA editor retiring: After more than 10 years at the helm of the Journal of the American Medical Association, Dr. Catherine DeAngelis has announced that she will leave her post as editor-inchief in June 2011 to develop "a Center for Professionalism in Medicine and the Related Professions, including nursing, public health, business and law" at Johns Hopkins University in Baltimore, Maryland. A statement from the JAMA $\&$ Archives journals group lauded her efforts to clean-up clinical trials. "Working with the International Committee of Medical Journal Editors, she encouraged other editors to agree to a requirement for all clinical trials to be registered as a condition of publication and to strengthen conflict of interest guidelines. In one of her most courageous stands as a journal editor, she instituted the requirement that industrysponsored clinical trials must have an independent academic statistician to review all data before a manuscript can be accepted and published in JAMA. No other journal has this stringent requirement to ensure the integrity of data," said the statement (www.digitalnews release.com/?q=JAMA_DeAngelis).

Wind and solar power: The Canadian Association of Physicians for the Environment (CAPE) says it will launch a campaign to dissuade Ontario from curbing renewable energy projects like wind turbines on the grounds that they somehow constitute a health hazard. "Compared with nuclear and coal, wind is actually very safe - both for humans and the environment," says Gideon Forman, executive director of the association. The Doctors Renewable Energy Project will involve "production of a 'myth buster' newsletter showing that renewable energy has less environmental impact than coal or nuclear; information booths at medical conferences to give doctors the facts about renewable energy; a media campaign, including letters to editor, opeds, TV and radio appearances, to compare renewables versus wind and coal; CAPE staff and doctors speaking at public meetings in communities where renewable energy is being considered; and doctors meeting with key energy decision-makers in government," Forman says.
Head injuries in sport: Concussions among children aged 8 to 19 playing five common team sports (basketball, football, baseball, soccer and ice hockey) in the United States more than doubled between 1997 and 2007, according to a study conducted by researchers at Hasbro Children's Hospital and Brown University in Providence, Rhode Island (Pediatrics 2010;126:e550-6). Of 502000 emergency room visits for concussions, more than 252000 were sports related, including $58 \%$ of all concussions for children aged 8 to 13 and $46 \%$ for children aged 14 to 19 . The rate of emergency department (ED) visits for concussion in organized team sports "seems to be highest in football and ice hockey, and the most ED visits for concussions in leisure and individual sports are in bicycling, playground activities, and snow skiing. In addition, ED visits for concussion in both age groups is on the rise, whereas participation in the top 5 OTSs [organized team sports] is declining," the authors concluded. Wayne Kondro, CMAJ

DOI:10.1503/cmaj.109-3664 